\title{
An unusual cause of metabolic alkalosis: hiding in plain sight
}

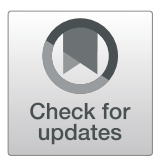

\author{
Carmen Elena Cervantes $^{1^{*}}\left(\mathbb{D}\right.$, Steven Menez ${ }^{1}$, Bernard G. Jaar ${ }^{1,2,3,4}$ and Mohamad Hanouneh ${ }^{1,2}$
}

\begin{abstract}
Background: Sodium bicarbonate, in the form of baking soda, is widely used as a home remedy, and as an additive for personal and household cleaning products. Its toxicity has previously been reported following oral ingestion in the setting of dyspepsia. However, its use as a non-ingested agent, like a toothpaste additive, has not been reported as a potential cause of toxicity.

Case presentation: We are reporting a case of an 80-year-old woman who presented with chronic metabolic alkalosis and hypokalemia secondary to exogenous alkali exposure from baking soda as a toothpaste additive, which might have represented an underreported ingestion of the substance.

Conclusions: Considering that one teaspoon of baking soda provides approximately 59 m-equivalents (mEq) of bicarbonate, specific questioning on its general use should be pursued in similar cases of chloride resistant metabolic alkalosis.
\end{abstract}

Keywords: Metabolic alkalosis, Hypokalemia, Baking soda, Sodium bicarbonate, Toxicity

\section{Background}

Sodium bicarbonate is widely known for its multiple uses as a home remedy and as an additive for personal and household cleaning products. As a strong base, it serves as a buffer to neutralize acid, and its consumer use stems from its properties as a deodorizing, degreasing, and cleaning agent. Sodium bicarbonate toxicity manifesting as metabolic alkalosis has previously been reported following oral ingestion in the setting of dyspepsia [1, 2]. However, its use as a non-ingested agent, like a toothpaste additive, has not been reported as a potential cause of toxicity.

\section{Case presentation}

An 80-year-old woman with a past medical history of long-standing hypertension leading to chronic kidney

\footnotetext{
* Correspondence: ccervan2@jhmi.edu

'Department of Medicine, Division of Nephrology, The Johns Hopkins

University School of Medicine, Baltimore, MD, USA

Full list of author information is available at the end of the article
}

disease (CKD) stage G3bA1 (baseline serum creatinine $1.4-1.78 \mathrm{mg} / \mathrm{dL}$ [123.7-157.35 umol/L], eGFR 33-45 $\mathrm{mL} / \mathrm{min}$ ), hyperlipidemia, atrial fibrillation and gastroesophageal reflux disease was referred to the Nephrology clinic by her primary care provider for evaluation of chronic metabolic alkalosis.

During her initial clinic visit, the patient endorsed decreased appetite and poor oral intake with resultant 5pound weight loss over the course of 6 weeks. She denied any nausea, vomiting or diarrhea. Her home medications included metoprolol tartrate $50 \mathrm{mg}$ twice daily, pravastatin $10 \mathrm{mg}$ daily, pantoprazole $40 \mathrm{mg}$ daily, rivaroxaban $15 \mathrm{mg}$ daily, and calcium carbonate $600 \mathrm{mg}$ daily. She specifically denied taking any additional medications, either prescribed or over-the-counter. On physical examination, the patient had a BMI of $17.2 \mathrm{~kg} / \mathrm{m}^{2}$, blood pressure of $160 / 80 \mathrm{mmHg}$ and heart rate of 80 beats per minute. She was clinically euvolemic on exam, particularly, there was no peripheral edema. Table 1 summarizes the patient's initial serum laboratory findings. Notably, her serum bicarbonate was elevated to 44 
Table 1 Laboratory results over time

\begin{tabular}{|c|c|c|c|c|c|}
\hline Labs & $\begin{array}{l}\text { Time Point 1: Initial } \\
\text { labs on presentation }\end{array}$ & $\begin{array}{l}\text { Time Point 2: } 3 \text { days after } \\
\text { stopping baking soda }\end{array}$ & $\begin{array}{l}\text { Time Pont 3: Following } \\
\text { resumption of baking soda us }\end{array}$ & $\begin{array}{l}\text { Time Point 4: } 3 \text { days after } \\
\text { re-stopping baking soda }\end{array}$ & $\begin{array}{l}\text { Reference } \\
\text { range }\end{array}$ \\
\hline Sodium & 146 & 140 & 145 & 141 & $135-148 \mathrm{mmol} / \mathrm{L}$ \\
\hline Potassium & 3.6 & 3.8 & 3.0 & 4.0 & $3.5-5.1 \mathrm{mmol} / \mathrm{L}$ \\
\hline Chloride & 95 & 98 & 100 & 102 & $96-109 \mathrm{mmol} / \mathrm{L}$ \\
\hline Bicarbonate & 44 & 34 & 39 & 32 & $21-31 \mathrm{mmol} / \mathrm{L}$ \\
\hline $\begin{array}{l}\text { Urea } \\
\text { Nitrogen }\end{array}$ & 8 & 9 & 9 & 6 & $7-22 \mathrm{mg} / \mathrm{dL}$ \\
\hline Creatinine & $\begin{array}{l}1.37 \\
(121.11)\end{array}$ & $\begin{array}{l}1.55 \\
(137.02)\end{array}$ & $\begin{array}{l}1.40 \\
(123.7)\end{array}$ & $\begin{array}{l}1.40 \\
(123.7)\end{array}$ & $\begin{array}{l}0.6-1.3 \mathrm{mg} / \mathrm{dL} \\
(53-114.9 \mathrm{umol} / \mathrm{L})\end{array}$ \\
\hline $\begin{array}{l}\text { Glomerular } \\
\text { Filtration Rate } \\
\text { (eGFR) }\end{array}$ & 45 & 40 & 44 & 44 & $\begin{array}{l}>6045 \mathrm{~mL} / \mathrm{min} / 1.73 \\
\mathrm{sqm}\end{array}$ \\
\hline Glucose & 103 & 91 & 91 & 83 & $71-99 \mathrm{mg} / \mathrm{dL}$ \\
\hline Calcium & 9.3 & 9.1 & 8.9 & 8.8 & $8.4-10.5 \mathrm{mg} / \mathrm{dL}$ \\
\hline Albumin & 3.7 & 3.9 & 3.7 & 3.7 & $3.5-5.5 \mathrm{~g} / \mathrm{dL}$ \\
\hline Magnesium & 2.0 & & & & $1.7-2.2 \mathrm{mg} / \mathrm{dL}$ \\
\hline \multicolumn{6}{|c|}{ Arterial Blood Gas } \\
\hline $\mathrm{pH}$ & 7.5 & & & & $7.35-7.45$ \\
\hline $\mathrm{PaCO} 2$ & $53.0(7.06 \mathrm{kPa})$ & & & & $\begin{array}{l}35-45 \mathrm{mmHg}(4.67-6 \\
\mathrm{kPa})\end{array}$ \\
\hline $\mathrm{HCO} 3$ & 41 & & & & $22-26 \mathrm{mEq} / \mathrm{L}$ \\
\hline
\end{tabular}

$\mathrm{mmol} / \mathrm{L}$, urinalysis was unremarkable, with no proteinuria or active urine sediment, and urine $\mathrm{pH}$ of 6.0 , which was somewhat lower than expected for her degree of metabolic alkalosis. Based on the arterial blood gas result with a $\mathrm{pH}$ of $7,50, \mathrm{CO} 253 \mathrm{mmHg}(7.06 \mathrm{kPa})$ and bicarbonate $41 \mathrm{mEq} / \mathrm{L}$, the patient was diagnosed with a primary compensated metabolic alkalosis. Spot urine electrolytes revealed the following: urine sodium of 41 $\mathrm{mmol} / \mathrm{L}$ (fractional excretion of $0.3 \%$ ), potassium 13.0 $\mathrm{mmol} / \mathrm{L}$ (fractional excretion $3.87 \%$ ) and chloride 48 $\mathrm{mmol} / \mathrm{L}$ (fractional excretion of $0.5 \%$ ), with a urine creatinine of $128 \mathrm{mg} / \mathrm{dL}(11,317 \mathrm{umol} / \mathrm{L})$. Her random urine chloride level greater than $20 \mathrm{mmol} / \mathrm{L}$ was indicative of a predominantly chloride-resistant metabolic alkalosis. In the setting of the patient's hypertension associated with metabolic alkalosis and tendency to hypokalemia, further workup was obtained after her serum potassium level was repleted to $3.8 \mathrm{mEq} / \mathrm{L}$, to rule out secondary causes of hypertension. Laboratory workup showed a serum renin level of $0.2 \mathrm{ng} / \mathrm{mL} / \mathrm{h}$ (reference: $0.25-5.82 \mathrm{ng} / \mathrm{mL}$ ) with normal serum aldosterone level of $3.6 \mathrm{ng} / \mathrm{dL}$ supine (Ref: if supine 3-16 ng/ $\mathrm{dl}$, upright less or equal to $28 \mathrm{ng} / \mathrm{dl}$ ) and AM cortisol level of $13.4 \mathrm{mcg} / \mathrm{dL}$ (Ref at 7-9 am: 4.6-23.4 mcg/dL). A computed tomography scan of her abdomen was obtained and showed normal-appearing adrenal glands. Further, renal vascular ultrasound was unremarkable with no evidence of renal artery stenosis.
Following initial extensive evaluation, the patient's medications were again reviewed at a subsequent visit, this time with her daughter present. Upon questioning specifically on the use of baking soda, her daughter reported that the patient had been brushing her teeth with this substance at least three times a day for the prior 6 months. The patient reported that her friend recommended it for her to improve her teeth hygiene. Upon discontinuation of this practice, repeat labs 3 days later showed significant improvement in her serum bicarbonate level to $34 \mathrm{mmol} / \mathrm{L}$, with a serum potassium level of $3.8 \mathrm{mmol} / \mathrm{L}$ (Table 1). However, the patient restarted brushing her teeth with baking soda and follow up labs showed again a higher serum bicarbonate of $39 \mathrm{mmol} / \mathrm{L}$ and a serum potassium of $3.0 \mathrm{mmol} / \mathrm{L}$ (Table 1). Again, following cessation of this practice, her repeat serum bicarbonate improved to $32 \mathrm{mmol} / \mathrm{L}$ with a serum potassium level of $4.0 \mathrm{mmol} / \mathrm{L}$ (Table 1 and Fig. 1). Her mild hypochloremia at presentation was most likely due to urine chloride loses (urine chloride was $48 \mathrm{mmol} / \mathrm{L}$ ), precipitated by volume expansion due to chronic sodium bicarbonate use.

\section{Discussion and conclusions}

This patient developed metabolic alkalosis due to exogenous alkali exposure from baking soda as a toothpaste additive, which to our knowledge has not been previously reported. Sodium bicarbonate toxicity in 


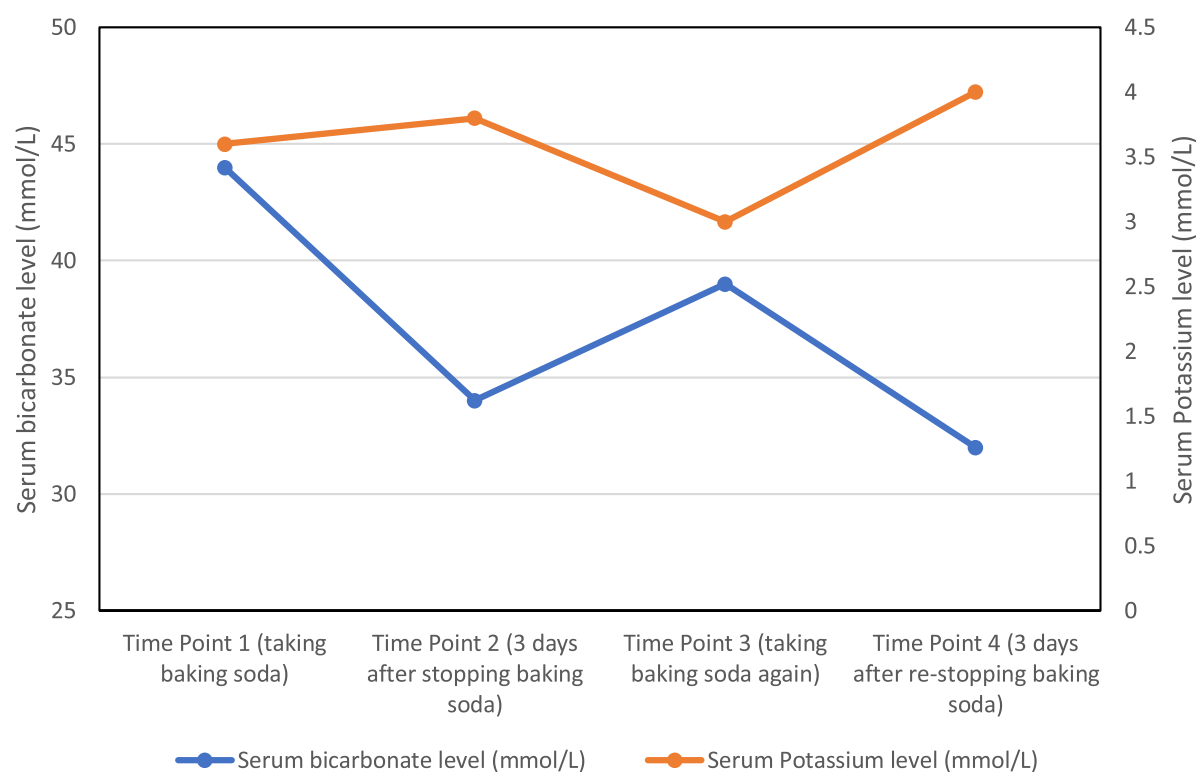

Fig. 1 Serum Bicarbonate and serum potassium trend during the course of evaluation/management

patients with CKD has been attributed to the impaired ability to excrete alkali loads [3]. This patient's CKD placed her at a higher risk for toxicity. It is noted that the patient was on a low dose of calcium carbonate which provided further bases but did not explain the severe alkalosis by itself. In addition, our patient's serum calcium level was normal. The fact that her alkalosis improved after cessation of baking soda on two separate occasions confirmed that this was the main source of her acid base derangement. It is conceivable that some people, for example those with some degree of cognitive impartment, may have small unintentional ingestion of toothpaste, which might have led to gastrointestinal absorption of baking soda in this patient's case. One teaspoon of baking soda provides approximately $59 \mathrm{~m}$-equivalents (mEq) of bicarbonate, while one 650-mg tablet of sodium bicarbonate provides only $7.7 \mathrm{mEq}$ of bicarbonate $[3,4]$. This explains the higher risk of alkalosis with a product that is widely available over the counter to all the population. Sodium bicarbonate toxicity is mostly related with its use as antacid and in smaller proportions as a strategy to cause false negative illicit drug tests and to treat UTIs [1-3]. Nonetheless, physicians should be aware of this common but underreported use of toxicity related to baking soda exposure.

\section{Abbreviations}

mEq: milli-equivalents; CKD: Chronic Kidney Disease; eGFR: estimated Glomerular Filtration Rate; BMI: Body mass index; UTIs: Urinary Tract Infections
Acknowledgements

Not applicable.

\section{Authors' contributions}

CEC wrote the first draft, MH and SM reviewed the manuscript and applied all the changes requested by co-authors, and BGJ reviewed the final versions and made the final edits prior to submission. All authors read and approved the final manuscript.

Funding

Not applicable.

Availability of data and materials

Not applicable.

Ethics approval and consent to participate

Not applicable.

\section{Consent for publication}

Written informed consent was obtained from the patient to publish the potentially identifiable information contained within the manuscript. A copy of the consent form is available for review by the editor of the journal from the corresponding author and can be provided on request.

\section{Competing interests}

The authors declare that they have no competing interests.

\section{Author details}

'Department of Medicine, Division of Nephrology, The Johns Hopkins University School of Medicine, Baltimore, MD, USA. ${ }^{2}$ The Welch Center for Prevention, Epidemiology, and Clinical Research, Baltimore, MD, USA. ${ }^{3}$ Department of Epidemiology, The Johns Hopkins Bloomberg School of Public Health, Baltimore, MD, USA. ${ }^{4}$ Nephrology Center of Maryland, Baltimore, MD, USA. 
Received: 1 April 2020 Accepted: 20 July 2020

Published online: 23 July 2020

\section{References}

1. Al-Abri SA, Kearney T. Baking soda misuse as a home remedy: case experience of the California poison control system. J Clin Pharm Ther. 2014; 39(1):73-7.

2. Ajbani K, Chansky ME, Baumann BM. Homespun remedy, homespun toxicity: baking soda ingestion for dyspepsia. J Emerg Med. 2011;40(4): e71-4.

3. Dubose TD. Metabolic Alkalosis. In: Gilbert S, Weiner D, editors. National Kidney FOundation Primer on Kidney Diseases; 2017. p. 137-43.

4. Yi JH, Han SW, Song JS, Kim HJ. Metabolic alkalosis from unsuspected ingestion: use of urine $\mathrm{pH}$ and anion gap. Am J Kidney Dis. 2012;59(4): 577-81.

\section{Publisher's Note}

Springer Nature remains neutral with regard to jurisdictional claims in published maps and institutional affiliations.

Ready to submit your research? Choose BMC and benefit from:

- fast, convenient online submission

- thorough peer review by experienced researchers in your field

- rapid publication on acceptance

- support for research data, including large and complex data types

- gold Open Access which fosters wider collaboration and increased citations

- maximum visibility for your research: over $100 \mathrm{M}$ website views per year

At $\mathrm{BMC}$, research is always in progress.

Learn more biomedcentral.com/submissions 